\title{
Oyster Planting Protocols To Deter Losses To Cownose Ray Predation
}

Roger L. Mann

Virginia Institute of Marine Science, rmann@vims.edu

Melissa Southworth

Virginia Institute of Marine Science, melsouth@vims.edu

Robert A. Fisher

Virginia Institute of Marine Science, rfisher@vims.edu

James A. Wesson

A. J. Erskine

See next page for additional authors

Follow this and additional works at: https://scholarworks.wm.edu/vimsarticles

Part of the Marine Biology Commons

\section{Recommended Citation}

Mann, Roger L.; Southworth, Melissa; Fisher, Robert A.; Wesson, James A.; Erskine, A. J.; and Leggett, T, "Oyster Planting Protocols To Deter Losses To Cownose Ray Predation" (2016). VIMS Articles. 309. https://scholarworks.wm.edu/vimsarticles/309 
Authors

Roger L. Mann, Melissa Southworth, Robert A. Fisher, James A. Wesson, A. J. Erskine, and T Leggett 


\title{
OYSTER PLANTING PROTOCOLS TO DETER LOSSES TO COWNOSE RAY PREDATION
}

\author{
ROGER MANN, ${ }^{1 *}$ MELISSA SOUTHWORTH, ${ }^{1}$ ROBERT J. FISHER, ${ }^{1}$ JAMES A. WESSON, ${ }^{2}$ \\ A. J. ERSKINE ${ }^{3}$ AND THOMAS LEGGETT ${ }^{4}$ \\ ${ }^{1}$ Department of Fisheries Science, Virginia Institute of Marine Science, College of William \& Mary, \\ Williamsburg, Gloucester Point, VA 23062; ${ }^{2}$ Virginia Marine Resources Commission, P.O. Box 756, \\ Newport News, VA 23607-0756; ${ }^{3}$ Cowart Seafood Corporation, 775 Lake Landing Drive, Lottsburg, \\ VA 22511; ${ }^{4}$ Chessie Seafood and Aquafarms, P.O. Box 412, Wicomico, VA 23184
}

\begin{abstract}
The utility of shell overlays to oyster (Crassostrea virginica) plantings as a cownose ray (Rhinoptera bonasus) predator deterrence mechanism was examined. Typical industry practice of oyster seed planting was followed in an experimental design employing treatment areas of $0.5-1.0$ acre (0.2-0.4 hectare). Areas were prepared in the Lower Machodoc Creek, Virginia, by the initial application of shell to insure a stable substrate under planted seed oysters. Seed oysters were planted using standard industry methods. Experimental areas were located, two upstream and two downstream, of a constriction in the Lower Machodoc that dictated differing physical environments in the respective locations with downstream locations being more exposed to northeast wind-driven stresses and, historically, a greater incidence of ray predation. Once oysters were planted, two of the areas, one upstream and one downstream of the aforementioned constriction, were additionally treated with a shell overlay as a predation deterrent. Oyster seed were planted in the experimental plots in February 2012. Market oysters were harvested from the experimental plots in December 2013 and January 2014. Final harvest data demonstrated that shell overlays do not offer additional protection to planted oyster seed with respect to possible cownose ray predation. Evidence of predation in the form of characteristically broken oyster valves were recorded in all treatment areas. Concurrent stomach content analysis of rays captured at the study location and observations of fouling community associated with the cultured oysters taken during the harvest operation indicate broad dietary preferences for rays when such a variety exists in the foraging region. For rays, oysters are not the singular preferred diet item, although localized and intensive feeding on oysters remains an option with a wide foraging range. Areas without overlay demonstrated higher production than those with shell overlay. Shell overlays are not recommended as predator deterrents for cownose rays in large deployments of unprotected oyster seed.
\end{abstract}

KEY WORDS: oysters, cownose rays, Crassostrea virginica, Rhinoptera bonasus, predation deterrence

\section{INTRODUCTION}

Enormous efforts are in progress both to restore the oyster [Crassostrea virginica (Gmelin, 1791)] resource of the Chesapeake Bay for ecological purposes, driven by Executive Order 13508 (2009), and to rebuild the commercial oyster industry (landings from the Virginia Chesapeake Bay have increased 12fold in the past decade). Both goals involve the placement of large numbers of oysters on the bay bottom in essentially unprotected environments that leave them subject to predation loss. Much has been debated on the role of cownose rays [Rhinoptera bonasus (Mitchill, 1815)] in predation losses of oysters thus planted (Smith \& Merriner 1985, reviews in Fisher 2009, Fisher et al. 2011, 2013). Rays are opportunistic, and their impacts can be locally very destructive leaving few, if any, oysters alive (Fisher et al. 2013). Two options exist to control losses to ray predation: reduce the number of predators and/or improve exclusion of predators. These are additive options, one does not exclude the other, but the options have differing data needs to adequately design the optimal approach, differing time courses of implementation, and differing scales of impact.

This study was designed to test a concept at commercial scale. Thus, units of reporting include both International System of units and those commonly used in Virginia commerce for oysters. Important conversions used in this manuscript are as follows: 1 VA bushel $=3003.9 \mathrm{inch}^{3}=$ $49.231 ; 1$ acre $=0.405$ hectare; 500 oysters $/$ bushel $=10.2$ oysters $/ 1 ; 1$ U.S. pint $=0.4731$

*Corresponding author. E-mail: rmann@vims.edu

DOI: $10.2983 / 035.035 .0114$
A directed fishery for rays would reduce the number of predators and thus, it is presumed, would reduce the loss of oysters to predation. It is technically feasible to harvest large numbers of cownose rays to develop attractive products; however, any fishery is dictated by regulations and guided by principles of sustainable harvest embodied in the Magnuson Stevens Fishery Conservation and Management Act (Public Law 94-265). These principles are based on a quantitative knowledge of the life history of the target species and a current stock assessment. There are significant data gaps in appropriate knowledge to develop a comprehensive management plan for cownose rays in the Chesapeake Bay. The cownose ray is a migratory, long-lived species with large body size, low fecundity, relatively late age of maturation, and distinct schooling and sexspecific behavior (Smith \& Merriner 1987, Grusha 2005). Even with the limited available data, these life history traits dictate that a sustainable harvest can only remove a modest percentage of the extant stock in any year, or the prospect of stock collapse arises (see Frisk 2010). There is a need for better life history data and a stock assessment to develop a management plan, but time is of the essence in developing an oyster industry-wide response to the ray threat. On a relative scale, the overall impact of ray harvest on oyster survival will be small, but locally its impact could be very high. The time frame for fishery implementation could be several years as a ray management plan evolves. The time and investment requirements for a fishery management plan provide only marginal comfort for both restoration advocates and the industry as the federal government invests millions of dollars and the industry is challenged daily by a suite of environmental and supply threats. A more timely control option is required. 
The development of exclusion approaches to protect bottom planted oyster seed from cownose ray predation is not a new idea, but it has been inadequately examined to date because of scales and cost issues. The project described herein was designed to provide a large-scale, "on the ground" experimental test that can be applied in both restoration and commercial enterprises, with data available in a reasonable time frame $(2 \mathrm{y})$. The project objective was to evaluate the practice of overplanting of oyster seed on the existing shell bed as a predator deterrence option to reduce or eliminate predation loss to cownose rays of those oyster seed when planted for either restoration or commercial purposes.

\section{MATERIALS AND METHODS}

Two sources of seed oysters are currently available to the restoration and commercial community. These are from traditional shell planting actions and spat on shell from aquaculture. Natural seed can be obtained in abundance in years of good recruitment, but they are unselected in terms of growth rate and disease tolerance and are available with a "date of birth" that is limited to a short time window that in turn dictates period and maximum size at planting. Spat on shell can be both selected for growth and disease tolerance and produced over a wider time window, which facilitates a desired size at time of planting, but they have a considerable price premium compared with natural seed. Data provided by either seed source are applicable to the other in extensive grow-out application.

The present study focused on shell "overplanting," that is, covering deployed seed with a light layer of shell as a deterrent to ray predation. The design required several stages of action including (1) preplanting preparation of the target area with shell to insure a uniform base on which the experimental study would be performed, (2) planting seed oysters by commercial large-scale methods at a density commensurate with commercial practice, (3) presence or absence (control) of post-plant overplanting with additional shell (understanding that this could increase subsequent harvest costs), and (4) varying harvest strategies if overplanting resulted in differing growth rates of planted oysters. Careful consideration of each of 1-4 stages was required in that each had modest ranges that, when considered in combination, provided a large matrix of final design options. Important in this design phase is realization that these "experiments" are large and difficult to implement with complete uniformity because the planting and harvest approaches use large barges and dredges - the tools of industry rather than experimental academics. This approach does, however, insure that final recommendations on optimal combinations will be applicable in real-world industry or at restoration scales. Indeed, the impacts of cownose ray predation are typically not that of an individual ray but of a school of rays with a signature in acres, and these schools can be very large (Blaylock 1989)

The range of values of each variable (1-4) were developed in concert with the industry partners, Cowart Seafood Corporation and Bevans Oyster Company, who have long-standing experience growing oysters at large scales, and the Virginia Marine Resources Commission, which also has prior experience with large-scale management and restoration efforts. The study was completed on commercial leases where there is a history of oyster production and ray predation. Choice of lease location



Figure 1. Study location in the Lower Machodoc Creek, a tributary on the southern shore of the Potomac River in the Chesapeake Bay, Virginia. See Materials and Methods section for additional details.

was critical in limiting variation in lease characteristics beyond experimentally determined variables.

The study site was on leased bottom at 1.5-4.0 m depth maintained by Cowart Seafood Corporation and Bevans Oyster Company in the Lower Machodoc Creek, Virginia (latitude, $38^{\circ}$ $8^{\prime \prime} 55^{\prime}$; longitude, $-76^{\circ} 39^{\prime \prime} 10^{\prime}$ ). This is a northward flowing tributary on the southern shore of the Potomac River (Fig. 1). There is restricted access into this body of water near the mouth of the river. Historically, ray predation was low upriver (south) and high downriver (north) of this feature. Thus, prospective low and high predation sites were chosen with respect to this geographical feature.

A pre-experimental survey was completed in February 2012 using a hydraulic patent tong $\left(1-\mathrm{m}^{2}\right.$ opening $)$ deployed from the Virginia Marine Resources Commission vessel R/V J.B. Baylor using the methods described by Mann et al. (2009) for oyster stock assessment. The surveys focused on resident populations of known ray prey items [infaunal Mya arenaria (Linne, 1758), Mercenaria mercenaria (Linne, 1758), Macoma balthica (Linne, 1758), Ensis sp. probably Ensis directus (Conrad, 1843), and epifaunal mussels, crabs, and amphipods]. Prior studies by Fisher (2010) found that stomach contents in rays captured adjacent to commercial oyster grounds were dominated by softshell clams, mussels, and crabs, not available oysters. The preexperimental surveys found minimal densities of these shellfish species in the target site areas. After the pre-experimental site survey, four experimental areas (A-D, see Fig. 1) were designated among the lease sites, and their corners marked with poles. The desired 1-acre minimum area size was achieved at three of the four areas: A (low predation, with shell overlay) = 0.52 acres ( 0.21 hectare); B (low predation, without shell overlay) $=1.06$ acres $(0.43$ hectare $)$ C (high predation, without shell overlay) $=1.13$ acres $(0.46$ hectare $)$; D (high predation with shell overlay $)=1.06$ acres $(0.43$ hectares $)$. The exception area, A, was considered a reasoned choice given that other area options required spatial separation of low predation treatments. The trade-off of proximity versus size weighed in favor of the smaller but closer selection of area A. All areas were subject to initial shell deployment, in February 2012, to insure a uniform base for planting. In total, 9,027 bushels $\left(444 \mathrm{~m}^{3}\right)$ were planted at the following rates: 3,978 bushels $\left(196 \mathrm{~m}^{3}\right)$ or 2,518 
bushels/acre $\left(50 \mathrm{~m}^{3} /\right.$ hectare) on the low predation (A and $\left.\mathrm{B}\right)$ areas, $5,049\left(249 \mathrm{~m}^{3}\right)$ bushels or 2,305 bushels/acre $\left(46 \mathrm{~m}^{3} /\right.$ hectare $)$ on the high predation $(\mathrm{C}$ and $\mathrm{D})$ areas. Additional comments on the stability of the planted regions over the time course of the study are presented with oyster harvesting data later in the Results section.

Seed oysters were obtained from the James River, Virginia. These were 2010 and 2011 recruits and were planted during the period February 15-28, 2012, at a target density of 1,281 bushels/acre $\left(25.5 \mathrm{~m}^{3} /\right.$ hectare). The density of seed per bushel was checked on three occasions during the seed planting process. Three replicate counts on the following dates provided the seed density estimates as follows: February $17=1,056$ oysters/ bushel (21.4 oysters/1), February $24=998$ oysters/bushel (20.3 oysters/1), and February $28=975$ oysters/bushel $(19.8$ oysters/1). A mean value $[(1,056+998+975) / 3]$ of 1,010 oysters/bushel $(20.5$ oysters/1) was obtained. At a planting density of 1,281 bushels/ acre this is equivalent to $1.3 \times 10^{6}$ oyster seed/acre or 320 seed oysters $/ \mathrm{m}^{2}$; all sizes included. A total of 4,828 bushels $\left(238 \mathrm{~m}^{3}\right)$ of seed were planted at 1,010 oysters/bushel for an estimated total of $4,876,280$ seed oysters.

Shell overplanting of the target areas was completed on March 5-9, 2012, at a density of 1,000-2,000 bushels/acre (2$41 / \mathrm{m}^{3}$ or $20-40 \mathrm{~m}^{3} /$ hectare). The overplanting rate was equivalent to a uniform layer of approximately $1-2$ shells thick. Monitoring of the prepared areas occurred on three occasions during the study period. A diver-based survey employing quarter meter square quadrats was completed on April 20, 2012, after the completion of shell overplanting. A second diver-based survey was completed on September 21, 2012, at the end of the first growing season. A third and final survey was completed on September 16, 2013, prior to harvest, this time using a hydraulic patent tong with a $1-\mathrm{m}^{2}$ opening (methods by Mann et al. 2009). Absolute density and shell length (SL; maximum dimension from hinge to the growing edge) demographics were recorded on all occasions. The September 2013 survey included examination for signatures of ray feeding on the crushed valves.

A challenge with all such sampling is adequacy of the sampling protocol. For stock assessment using the hydraulic patent tong, the recommendation of Bros and Cowell (1987) was followed by plotting the SEM with increasing sample number $(n)$ within a defined stratum (area), with sampling considered to be robust (i.e., increased sampling produces sequentially less useful information) when the slope of the plot decreased. The location of individual samples is typically set by locating a virtual grid over a plot of the stratum, labeling the intersections of the grid sequentially, and choosing the sampling sequence of these intersecting points using a random number generator. In stock assessment mode (see Mann et al. 2009), this protocol defines georeferences for each of the intersecting grid points and thus sampling points. These are located in the field using the Global Positioning System (GPS) on the sampling vessel. For the current study, a defined series of georeferenced points sampled in sequence was not possible because the area to be sampled was very small and the combination of errors in the GPS location in the field combined with the inability to maintain the vessel exactly in the desired location (wind and tide driven) resulted in a series of effective sampling zones with considerable overlap. Thus, the approach in both diver and patent tong sampling was to use a series of haphazardly chosen sample points within the area boundaries as set in the field by the permanent corner markers. Real-time plots were made of SEM versus $n$ in the field: coherence of the SEM values was consistently observed at sample 5 and the decreasing trend of the SEM value as $n$ increased from 5 to 10 .

Oyster harvest was completed between December 16, 2013, and January 9, 2014, using a 24-inch $(60 \mathrm{~cm})$ wide oyster dredge operated from a skiff. The collective industry experience has shown it to be more cost-effective to harvest a complete shell plant rather than sort by size and return smaller oysters. Additional data were collected on December 16-17, 2013, to describe number of oysters/bushel and incidence of ray signatures on broken shells included in the harvest material.

Observations during harvest suggested that oysters were not evenly distributed throughout the entire original area footprints and that actions of sand migration, siltation, burial, and/or physical movement of seed by tidal and storm action may have modified the original distributions during the two year study period. Thus, a postharvest resurvey of the four areas was completed on March 10, 2014, using standard surveying techniques (Leica 1200 Series GPS, connected to Smartnet reference network) that locate to the centimeter level (finer than the ability to function from a small boat given vessel movement). The survey relocated the area perimeter markers, then ran parallel transects at less than 10-m intervals from boundary to boundary within each area until the entire area footprint had been covered. Along transects the bottom was sampled by sounding pole at 3- to 5-m intervals. Locations where shell appeared or disappeared were digitally marked by the surveyor, and subsequently replotted as an overlay on the original survey plots. Areas A and B (Fig. 2A) had very minor modification; however, this was not the case for areas C and D (Fig. 2B).

Area A was generally softer than area B. The western perimeter, line 8-9 to 5 in Figure 2A, was slightly softer than the inshore eastern perimeter even though shells were still present. The possibility of mud/sand cover was possible but difficult to determine with certainty, thus no downward adjustment of shell coverage area was made for final density estimates. Area B was well supplied with shell, even extending slightly over the boundaries on the western (offshore) perimeter. The total shell coverage on area A after preparation and seed addition in April 2012 was thicker than on area B (Fig. 3B), but the two were comparable by September 2013. Area C, initially planted without a shell overlay, was only deficient in shell at its southernmost corner (point 7 in Fig. 2B where hard sand prevailed) in March 2014. Overall, the bottom in area $\mathrm{C}$ was much better than area $\mathrm{D}$; the bottom was harder, and there were more shells, even multiple layers of shells along the northern boundary from points 5 to 8 . The depths at points N9-N13 were $1.5,1.8,0.9,1.2$, and $2.1 \mathrm{~m}$, respectively. The exposed shell layer was thin throughout area $\mathrm{D}$, despite being the location with an initial overlay and higher initial total shell density (Fig. 3B). Approximately half of area D had lost its shell cover to burial over the time course of the study. The sequence of data points from N1 to N8 in the March 2014 survey is as follows: N1 at $3.66 \mathrm{~m}$ had shell present and N2 at $3.05 \mathrm{~m}$, a sand layer, had buried shell approximately $15 \mathrm{~cm}$ below the surface. Transects on an east-west plane originating at locations N3 $(3.05 \mathrm{~m}$ depth), N4 (2.45 m), and N5 (2.75 m) all had surface shell. The northwest corner of the area had buried shell (approximately $10 \mathrm{~cm}$ below the surface) at location N6 $(2.75 \mathrm{~m})$. The marginal surface shell at N7 $(3.35 \mathrm{~m})$ had disappeared by N8 $(2.75 \mathrm{~m})$, as 



Figure 2. Resurvey of (A) areas $A$ and $B$ and (B) areas $C$ and $D$ postharvest. Sequence 1-9 in A defines original boundaries in area $A$ and B. Sequence 1-8 in B defines original boundaries in areas C and D. Sequence N1-N13 in B defines postharvest boundaries in areas C and D.

the survey progressed in an easterly direction along the northern perimeter of the area.

Cownose rays were sampled for gut analysis using tended longline fishing gear from May through September 2012, with fishing effort directed when rays were visually observed within the research plot areas. Longlines consisted of $90 \mathrm{~kg}$ breaking strain monofilament ground line, $100 \mathrm{~m}$ in length, with 2-m gangions placed $10 \mathrm{~m}$ apart with 30 size $14 / 0$ circle hooks per line. Long lines were baited with either menhaden [Brevoortia tyrannus (Latrobe, 1802)] or peeler crabs [Callinectes sapidus (Rathbun, 1896)] and fished twice per day (2-4 h soak time) to target cownose rays. Upon capture, rays were placed on ice, boxed, and delivered to Virginia Institute of Marine Science for necropsy. Stomachs were removed by severing the esophagus as it entered the peritoneal cavity at the cranial side of digestive tract and where the stomach leads into the spiral intestine on the caudal side. Removed stomachs were placed in plastic whirlpack bags, frozen, and held in freezer cold storage until processed 4-6 wk post collection. Frozen stomachs were thawed in cool water within sealed sample bags for $1-4 \mathrm{~h}$ depending on the size. Once thawed, full stomach wet weights were recorded to the nearest milligram on an electronic analytical balance. The stomach contents were then emptied into a petri dish for sorting and identification, and the empty stomach was weighed. The overall stomach contents weight was then calculated by the difference of weights.

With the use of field guides and taxonomic keys, prey items were identified to the lowest possible taxon and sorted for collective weights for each food category. Shell fragments of bivalves were identified to lowest possible taxon and sometimes to species if sufficient characteristic attributes were found (e.g., hinges). Enumeration of prey items was not feasible due to the level of mastication of food items. Each food category was weighed to the nearest milligram. The total weight of each food category was expressed as a percentage of the overall weight of the stomach contents. Results of stomach content analysis were reported as occurrence of prey items and percent of observed prey items in stomachs with quantifiable contents. Spiral valves were sampled with stomachs to insure there were no prey items missed, especially hard prey items that are frequently retained longer within the ray digestive system. Examination of spiral valves in conjunction with stomachs provide for better enumeration of hard-bodied prey in cownose ray diet (Fisher 2010).

\section{RESULTS}

Changes in absolute density of oysters (includes all size classes), live shell abundance (includes only shell with live oysters attached), and blank shell abundance (includes all other shell) measured on each of the three monitoring dates are shown in Figure 3. The initial survey oyster densities for areas $\mathrm{A}-\mathrm{C}$ by diver survey exhibit both considerable variance within an area (note error bars in Fig. 3A) and differences between areas A-C and area $\mathrm{D}$, with the latter having higher mean values $(90$ 130 oysters $/ \mathrm{m}^{2}$ versus approximately 320 oysters $/ \mathrm{m}^{2}$ ). The latter value is in agreement with the densities based on seed planting 

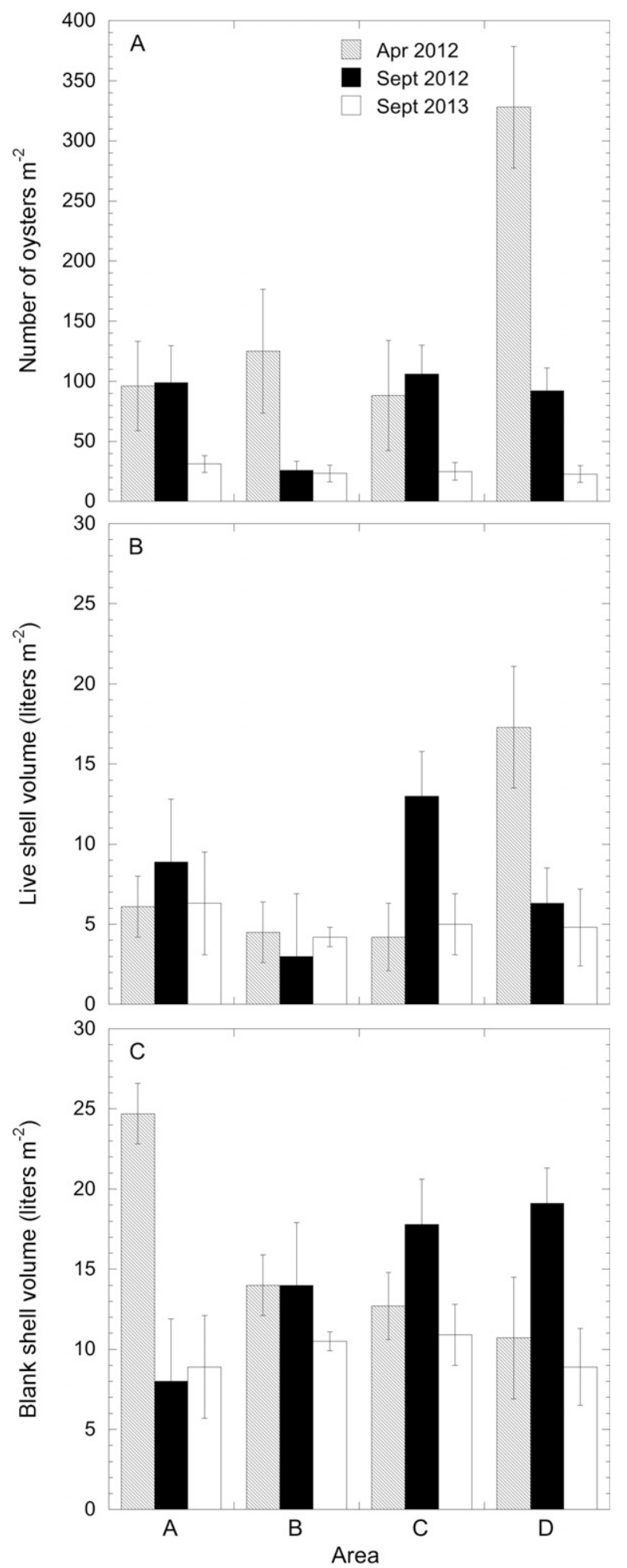

Figure 3. (A) Changes in absolute density (mean $\pm \mathrm{SEM} / \mathrm{m}^{2}$, all size classes included), (B) live shell volume $\left(1 / \mathrm{m}^{2}\right)$, and (C) blank shell volume $\left(\mathrm{l} / \mathrm{m}^{2}\right)$ for three monitoring dates. April $2012(n$ values for $\mathrm{A}=6, \mathrm{~B}=\mathbf{8}$, $\mathrm{C}=7$, and $\mathrm{D}=6$ ) and September $2012(n$ values for $\mathrm{A}=5, \mathrm{~B}=4, \mathrm{C}=4$, and $D=7)$ by diver $\left(0.25 \mathrm{~m}^{2}\right.$ quadrat $)$ and September 2013 by patent tong $\left(1.0 \mathrm{~m}^{2}, n=10\right.$ all sites). Areas: A, low predation with shell overlay; B, low predation with no shell overlay; $C$, high predation with no shell overlay; and $\mathrm{D}$, high predation with shell overlay. (see above section Materials and Methods on natural oyster seed planting). The data emphasize the patchy nature of the planting process plus the difficulty of diver-based sampling in near zero visibility. September 2012 sampling gave comparable mean values for density in areas $\mathrm{A}, \mathrm{B}$, and $\mathrm{D}$ (range $=90$ 120 oysters $/ \mathrm{m}^{2}$ ) but lower density in area C (approximately 30 oysters $/ \mathrm{m}^{2}$ ). In the September 2013 sampling, with patent tongs, all densities were reduced to approximately 20-30 oysters $/ \mathrm{m}^{2}$. Figure $3 \mathrm{~B}$, and $\mathrm{C}$ portrays density $\left(1 / \mathrm{m}^{2}\right)$ of shell associated with live oyster and blank shell, respectively. The former is a direct product of seed oyster planting whereas the latter originates in both the initial shell deployment and, in areas A and D, shell overlay. The standard errors shown in Figure $3 \mathrm{~B}$ again indicate the patchiness of seed oyster planting. The time course of decreasing density of oysters in Figure 3A illustrates mortality; however, the live associated shell volumes of surviving oysters remain reasonably stable over time as increasing individual size offsets decreasing numbers. The shell overlay in area A produced a notably higher shell density $\left(25 \mathrm{l} / \mathrm{m}^{2}\right)$ in April 2012 than at subsequent samplings $\left(8-9 \mathrm{l} / \mathrm{m}^{2}\right)$. Area B demonstrates little variation in shell over the time course of the study. Both areas $\mathrm{C}$ and D demonstrate marginally higher shell densities in September 2012 than in either April 2012 or September 2013. These mid-study increases may have been in part reflective of addition of shell by mortality of growing oysters. In the same manner, mortality between September 2012 and 2013 (Fig. 3A) would contribute to changes in the shell resources as illustrated in the September 2013 values shown in Figure 3C.

Figures 4-7 summarize changes in population demographics (as percentage in size category versus SL in 5-mm intervals) for the four experimental areas (A-D, respectively, in sequence) for the three monitoring dates.

A clear progression of growth in the population is evident in area A (shell overlay) over the time course of the study (Fig. 4). Note again that the initial seed planting contained 2-y classes of recruitment, 2010 and 2011, and were planted in early 2012. Thus, no growth would be expected in calendar 2012 prior to planting. The 2010 class is notable as a presence between 56 and $76 \mathrm{~mm}$ SL with a mode at $61-65 \mathrm{~mm}$ SL. This is commensurate with growth expectancy for the James River as described by Mann et al. (2009). The 2011 class has a presence between 20 and $55 \mathrm{~mm} \mathrm{SL}$ with highest abundance in the $26-45 \mathrm{~mm} \mathrm{SL}$ range. By September 2012, the demographic spread from 46$100 \mathrm{~mm}$ SL with size classes through $85 \mathrm{~mm}$ SL all being well represented. Approximately $32 \%$ were in excess of the market size of $76 \mathrm{~mm} \mathrm{SL}$. The smallest of the 2010 class had "merged" with the largest of the 2011 class by the September 2012 sampling. By September 2013, essentially all oysters were in excess of $60 \mathrm{~mm}$ SL with the major peak occupying broad distribution between 70 and $120 \mathrm{~mm} \mathrm{SL}$-approximately $80 \%$ were in excess of the market size of $76 \mathrm{~mm}$ SL.

Area B (no shell overlay) illustrated similar postplanting demographics to area A but with additional oysters in the 50-70 mm SL classes suggesting some inclusion of 2009 class individuals in the James River seed (Fig. 5). By September 2012, the dominant size classes were between 51 and $90 \mathrm{~mm} \mathrm{SL}$, with $28 \%$ at market size and another $12 \%$ in the $71-75 \mathrm{~mm}$ SL range. By September 2013, approximately $80 \%$ were at market size with the 86 $95 \mathrm{~mm}$ SL classes being the largest by percentage.

Area C (no shell overlay) had similar demographics to area A post planting (Fig. 6). By Fall 2012, the demographic had 


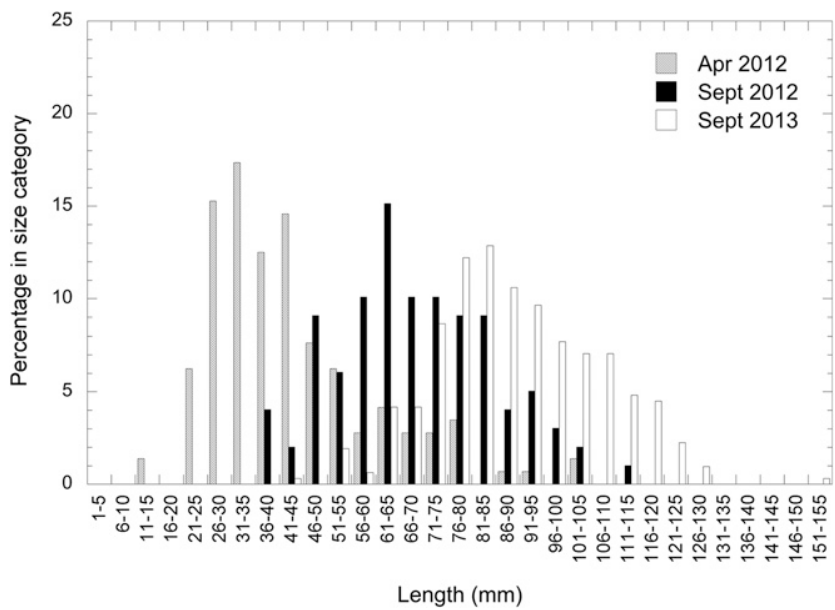

Figure 4. Population demographics in area A (low predation, with shell overlay).

notable representation in all size classes between 41 and $80 \mathrm{~mm}$ SL, with $22 \%$ of the total at or above market size. By September $2013,35 \%$ were still below market size, although $14 \%$ were in the 71-75 mm SL class, just below market size. The dominant size classes were between 71 and $85 \mathrm{~mm} \mathrm{SL}$, representing $43 \%$ of the total demographic. Only $33 \%$ were $86 \mathrm{~mm} \mathrm{SL}$ or larger, compared with $55 \%$ for the same size interval in area B.

Area D (shell overlay) had, again, similar demographics to area A post planting (Fig. 7). By September 2012, only $14 \%$ were above market size with dominant size classes at 51-60 and $71-75 \mathrm{~mm}$ SL representing $50 \%$ of the total demographic. By September 2013, 38\% remained below market size with the 76$95 \mathrm{~mm}$ SL classes representing $52 \%$ of the total demographic.

Growth progression was observed in all areas, although the percentages at or above market size by the September 2013 preharvest sampling were greater in areas $\mathrm{A}$ and $\mathrm{B}(80 \%$ in both) than in areas $\mathrm{C}$ and $\mathrm{D}$ (65\% and $62 \%$, respectively).

Oyster harvest was completed in late December 2013 and early January 2014 (Table 1). A total of 2,160.5 bushels $\left(106 \mathrm{~m}^{3}\right)$ of oysters were harvested. Given that 4,828 bushels of seed oysters were initially planted, the return is 0.45 bushels of market oysters for each bushel of seed planted. This is a typical industry return. Overall survival from seed to harvest requires an estimate of market oysters per bushel. A typical value for $76 \mathrm{~mm}$ SL oysters is 350 /bushel or 756,175 market oysters. This value may be high given the large size of oysters in a subsample collected at final harvest (Table 2). Using the 350/bushel estimate gives a value of $(756,175 / 4,876,280) 0.155$ or $15.5 \%$ survival from seed to harvest size. Two features of the data in Table 1 are notable. The first is the decrease in harvest per day (catch per unit effort) in successive harvest days when full days of effort were focused on a particular area. This is to be expected. When plotted as catch per unit effort versus day of effort (not shown), these data decline in a linear manner for each area in agreement with the expectation of a Leslie-DeLury estimator (Leslie \& Davis 1939, DeLury 1947). The second feature is the marked difference in total harvest among the four areas.

Consideration of the differences in harvest by area (Table 1) is a stepwise process. The initial examination focused on planting area, harvest, and presence or absence of overlay.
The upstream area with shell overlay (A) had an initial area of 0.52 acres and produced 229.5 bushels $\left(11.3 \mathrm{~m}^{3}\right)$ of oysters. The upstream area without shell overlay (B) had an initial area of 1.06 acres and produced $1,018.5$ bushels $\left(50.14 \mathrm{~m}^{3}\right)$. The downstream area without shell overlay (C) had an initial area of 1.13 acres and produced 713.5 bushels $\left(35.1 \mathrm{~m}^{3}\right)$ of oysters. The downstream area with shell overlay (D) had an initial area of 1.06 acres and produced 199 bushels $\left(9.8 \mathrm{~m}^{3}\right)$ of oysters. When expressed as per acre production values these are as follows: upstream with shell overlay (A) at 441 bushels/acre $\left(8.8 \mathrm{~m}^{3} /\right.$ hectare $)$, upstream without shell overlay (B) at 961 bushels/acre $\left(19.2 \mathrm{~m}^{3} /\right.$ hectare), downstream without shell overlay (C) at 631 bushels/acre $\left(12.6 \mathrm{~m}^{3} /\right.$ hectare $)$, and downstream with shell overlay (D) at 188 bushels/acre $\left(9.25 \mathrm{~m}^{3} /\right.$ hectare). These mean values are strongly indicative that a shell overlay is not conducive to oyster production. Meat yields are an industry measure of shucked wet tissue per bushel of oysters harvested. This is a volume:volume ratio typically in units of U.S. pints (1 pint $=0.4731)$ per Virginia bushel (49.23 1). Harvests from individual areas were not separated in subsequent processing. Daily yields varied between 5.87 and 7.08 pints/bushel with a weighted mean for the complete harvest of $6.21 \mathrm{pints} /$ bushel.

As noted in the Materials and Methods section, the actions of sand migration, siltation, burial, and/or physical movement of seed by tidal and storm action must be considered with respect to the postharvest survey results. The revised estimates of coverage for areas $\mathrm{C}$ and $\mathrm{D}$ are 0.8 and 0.37 acres $(0.32$ and 0.15 hectares), respectively (see also Fig. 2B). This represents $29 \%$ and $65 \%$ reductions in coverage respectively for areas $\mathrm{C}$ and $\mathrm{D}$. Area $\mathrm{C}$ and especially area $\mathrm{D}$ are subject to northeasterly winds and storm events. Thus, some loss of bottom coverage on the northerly flank of area D is explained. Oysters may have moved as part of associated bed transport from the southern flank of area D to area C. Some shell was noted beyond the western boundary of area $\mathrm{C}$ as would be expected from such wind stress. Perimeter losses on both the western and eastern flanks of area D and the southern corner of area C appear to be related to sand movement in shallow water. The western (deeper) boundary of area A was not substantially revised to lower the final coverage for area A. Nonetheless, sedimentation

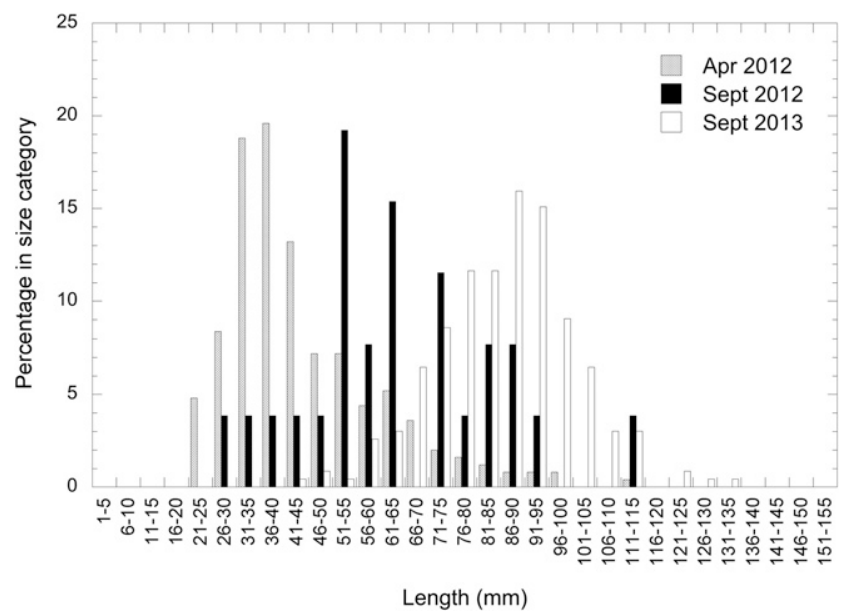

Figure 5. Population demographics in area B (low predation, no shell overlay). 




Figure 6. Population demographics in area $\mathrm{C}$ (high predation, no shell overlay).

appears to have been prevalent across the entire footprint of area $\mathrm{A}$ where shell was much less prevalent in the final survey than for area $\mathrm{B}$. The revised final densities at the time of harvest were recalculated as follows. Area A (shell overlay) maintained at 0.52 acres and produced 229.5 bushels of oysters. Area B (no shell overlay) maintained at 1.06 acres and produced $1,018.5$ bushels. Area $\mathrm{C}$ (no shell overlay) decreased to 0.8 acres $(0.32$ hectares) and produced 713.5 bushels of oysters. Area D (shell overlay) decreased to 0.37 acres $(0.15$ hectares $)$ and produced 199 bushels of oysters. When expressed as per acre production values, the final densities are as follows: A at 441 bushels/acre, B at 961 bushels/acre, C at 892 bushels/acre, and D at 537 bushels/ acre $\left(8.8,19.2,17.8\right.$, and $10.7 \mathrm{~m}^{3} /$ hectare, respectively). Again, the data demonstrate higher spatial production in areas without initial shell overplanting.

Ray predation on oysters leaves distinct clean breaks in crushed shell signatures. Examples are shown in Figure 8 from the September 2013 sampling using patent tongs. Field observations from December 16 to 17, 2013, are summarized in Table 2. Critical in this summary is a consideration of the topography of the bottom within the study areas as well as that data were purposely collected on the first two days of the harvest activity.

During December 16-17, 2013, harvesters towed dredges over the main bodies of the areas to break any crustal formation that had developed in the near $2 \mathrm{y}$ undisturbed period since seed planting. The nature of the harvest data in Table 2 does not allow comprehensive statistical comparisons - the $n$ values of tows are modest at three dredge tows sampled for each area for each of the sampling days. In all instances, bushels of oysters per tow retained were in the range 0.9-1.6 inclusive of all areas on both days. Area A had a mean of 262 oysters/ bushel (5.3/1 both days) compared with 211 oysters/bushel $(4.3 / 1)$ for area B, indicating larger oysters in area B where overlay was absent. This observation is in agreement with the September 2013 patent tong data. The number of signatures per bushel of collected material was not reduced by the presence of a shell overlay. The mean value (14.4/bushel) for area A was the highest of the four treatments compared with only 3.9 /bushel in the adjacent area B. A value of 12.4 /bushel was observed on December 16, 2013, in area C, but this was reduced to 3.9 the following day. Similarly, the observation for

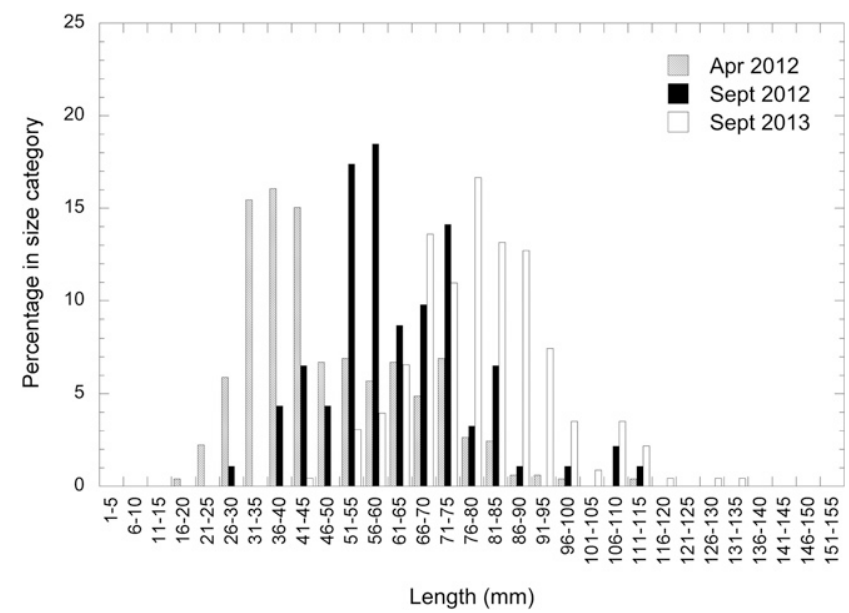

Figure 7. Population demographics in area D (high predation, with shell overlay).

area D decreased from 5.9 to $1.9 /$ bushel from December 16 to 17, 2013. This range of values corresponds to mortality values, estimated from signatures and oyster per bushel values, from $1.45 \%$ (low) to $7.9 \%$ (high) that can be ascribed to ray predation on market size oysters in the current study. Of final and additional note is the concordance between volumes of oysters and shell retained in each tow (fifth and sixth columns in Table 2). The general parity of these values is in general agreement with the September 2013 data illustrated in Figure 3B, C.

A total of five adult cownose rays, four females and one male, were collected from experimental plots in June-July 2012; three from the outside plots and two from the inside plots (Table 3). Two of the females (rays 3 and 4) were carrying near-term embryos, both males with disc widths of 39 and 41.5 $\mathrm{mm}$, respectively. The stomachs and spiral valves of each cownose ray were analyzed for prey items. Some teleost

TABLE 1.

Daily oyster harvest, in bushels, for experimental areas (A-D) from December 16, 2013 to January 9, 2014.

\begin{tabular}{lrccccc}
\hline \multicolumn{1}{c}{ Date } & A & B & C & D & Total & Yield \\
\hline December 16, 2013 & 11 & 134 & 119.5 & 11 & 275.5 & 6.12 \\
December 17, 2013 & 0 & 139.5 & 126 & 0 & 265.5 & 6.12 \\
December 18, 2013 & 136 & 121 & 0 & 0 & 257 & 6.07 \\
December 19, 2013 & 0 & 111 & 135.5 & 0 & 246.5 & 6.45 \\
December 20, 2013 & 0 & 121 & 124 & 0 & 245 & 5.87 \\
December 23, 2013 & 0 & 98 & 0 & 112.5 & 210.5 & 5.87 \\
December 21, 2013 & 0 & 92.5 & 79 & 0 & 171.5 & 6.25 \\
December 26, 2013 & 0 & 73 & 64 & 0 & 137 & 6.33 \\
December 27, 2013 & 0 & 64 & 0 & 53.5 & 117.5 & 6.33 \\
December 30, 2013 & 0 & 33 & 37 & 0 & 70 & 6.74 \\
December 31, 2013 & 31.5 & 0 & 28.5 & 0 & 60 & 6.74 \\
January 2, 2014 & 27 & 31.5 & 0 & 0 & 58.5 & 6.74 \\
January 9, 2014 & 24 & 0 & 0 & 22 & 46 & 7.08 \\
Total (bushels) & 229.5 & $1,018.50$ & 713.5 & 199 & $2,160.5$ & - \\
Total (m ${ }^{3}$ ) & 11.3 & 50.1 & 35.1 & 9.8 & 106.4 & - \\
\hline
\end{tabular}

Yield data are in pints of meat/bushel of harvested oyster (see text for additional details). 
TABLE 2.

Oyster harvest dredge tows on December 16 and 17, 2013: oyster and shell abundance and signatures of ray predation.

\begin{tabular}{|c|c|c|c|c|c|c|}
\hline Area & Date & Overlay Y/N & Oysters (no./bu) & Oysters (bu/tow) & Shell (bu/tow) & Signature (no./bu) \\
\hline \multirow[t]{3}{*}{ A } & December 16, 2013 & $\mathrm{Y}$ & 230 & 1.2 & 1.0 & 18.1 \\
\hline & December 17, 2013 & $\mathrm{Y}$ & 294 & 1.1 & 1.0 & 10.4 \\
\hline & All & $\mathrm{Y}$ & 262 & 1.2 & 1.0 & 14.4 \\
\hline \multirow[t]{3}{*}{$\mathrm{B}$} & December 16, 2013 & $\mathrm{~N}$ & 287 & 1.5 & 0.8 & 4.1 \\
\hline & December 17, 2013 & $\mathrm{~N}$ & 235 & 1.8 & 1.0 & 3.8 \\
\hline & All & $\mathrm{N}$ & 211 & 1.6 & 0.9 & 3.9 \\
\hline \multirow[t]{3}{*}{$\mathrm{C}$} & December 16, 2013 & $\mathrm{Y}$ & 79 & 0.9 & 1.7 & 12.4 \\
\hline & December 17, 2013 & $\mathrm{Y}$ & 64 & 1.1 & 1.2 & 3.9 \\
\hline & All & $\mathrm{Y}$ & 0 & 1.0 & 1.4 & 7.7 \\
\hline \multirow[t]{3}{*}{$\mathrm{D}$} & December 16, 2013 & $\mathrm{~N}$ & 37 & 1.6 & 0.7 & 5.9 \\
\hline & December 17, 2013 & $\mathrm{~N}$ & 28.5 & 1.4 & 1.2 & 1.9 \\
\hline & All & $\mathrm{N}$ & 0 & 1.5 & 0.9 & 4.0 \\
\hline
\end{tabular}

$\mathrm{Y}$, yes; N, no; bu, bushel. Values are means of three dredge tows for each area on each date.

remains were present, but were identified as bait (Brevoortia tyrannus) and not considered a prey item. Examination of spiral valves in conjunction with stomachs provided better enumeration of hard-bodied prey in cownose ray diet. Most prey flesh remnants found in the spiral valve were beyond recognition due to advanced digestion. Retention of nondigestible hard parts of certain prey in the spiral valve was largely identifiable to at least prey category and some to species level.

From the five rays collected, stomachs were completely empty in rays 1,2 , and 5 , with only a small quantity $(0.42 \mathrm{~g})$ of detritus (woody) found in the stomach of ray 4 . The spiral valves of rays 2 and 5 were also completely empty. Prey items were found in the stomach of ray 3 and in the spiral valves of rays 1,3 , and 4 (Table 4 ). Though the sample size was small in this study, prey items were dominated by thin-shelled bivalves
[Tagelus plebius (Lightfoot, 1786), Ischadium recurvum (Rafinesque, 1820), and Mercenaria mercenaria] and crustaceans [Callinectes sapidus, Eurypanopeus depressus (MilneEdwards, 1880), and Rhithropanopeus harrisii (Gould, 1841)]. Oysters were not observed as a primary prey item.

The weight and volume of stomach and spiral valve content, when present, was relatively small with little to no soft tissue of prey items remaining. Hard structure of prey items (bivalve shell, crustacean exoskeleton) dominated content. These observations, together with those of stomachs and spiral valves void of content, suggest that rays may have been harvested between feeding periods. In such situations, softbodied prey items would have already been digested. This appears to be the case in each of the samples collected in this study in that no benthic worms were represented. A



Figure 8. Ray predation signatures in shells of consumed oysters collected from the experimental areas in September 2013. 
TABLE 3.

Summary of cownose rays collected near the experimental areas in June and July 2012 for stomach content analysis.

\begin{tabular}{cccccc}
\hline \hline Ray no. & $\begin{array}{c}\text { Date } \\
\text { collected }\end{array}$ & Sex & DW (mm) & $\begin{array}{c}\text { Plot } \\
\text { (inside/outside) }\end{array}$ & $\begin{array}{c}\text { Embryo } \\
\text { present (Y/N) }\end{array}$ \\
\hline 1 & June 21 & F & 98 & Inside & N \\
2 & June 25 & M & 83.5 & Outside & N/A \\
3 & June 25 & F & 99 & Outside & Y \\
4 & June 25 & F & 98 & Outside & Y \\
5 & July 18 & F & 101.5 & Inside & N \\
\hline
\end{tabular}

DW, disc width; F, female; M, male; Y, yes; N, no; N/A, not applicable. Inside plots are those upriver of the constriction (areas A and B) and outside plots are those downriver of the constriction (areas C and D) as discussed in the Materials and Methods section.

comparison of prey diversity between areas is limited because rays 1 and 5 (collected from inside plots) were devoid of prey items in their stomachs; however, Tagelus sp. was recorded in both the spiral valve of ray 5 and rays 3 and 4 collected from outside plots. In this study, Brevoortia and Callinectes items found in rays were most likely the result of bait ingested upon capture.

\section{DISCUSSION}

Natural oyster reefs have complex vertical topography with a base of consolidated shell and sediment and an overlay of aggregated living material. Cownose ray's general foraging behavior would be challenged by such a cohesive structure. Centuries of harvest have degraded and disaggregated natural reefs in the Chesapeake Bay, and restorative reef rebuilding to precolonial, three-dimensional complex aggregate form will require decades of undisturbed natural growth. In the interim, restoration is focused on building structure with addition of oysters or simply rebuilding structure and allowing the natural progression of recruitment, growth, and mortality to stabilize and perpetuate the provided foundation. Thus, initial stages of restoration often provide limited three-dimensional structure and comparatively loose aggregation of underlying structure. Any overlaying oysters would not be part of the cemented structure and thus would be susceptible to cownose ray foraging. Natural reefs are not and have not historically been the only source of harvested oysters in Virginia. The surveys of Baylor (1894) outlined the boundaries of the "natural oyster beds, rocks, and shoals" for public harvest (common property doctrine, accessed through purchase of a license from the Commonwealth of Virginia). In addition, approximately 100,000 acres (40,000 hectares) of bottom area outside the Baylor designated natural beds, rocks, and shoals have been available for private leasing for oyster culture for over a century and have been major contributors to the overall oyster production for most of that period.

Leasable areas generally range in bottom type from hard sand to sand-mud mixes and are devoid of natural oyster reefs. Prior to planting of seed, lease areas are typically prepared with a shell substrate as a foundation for the subsequent seed. Again, these constructs, like the early stages of restoration described above, are not consolidated aggregates and are therefore susceptible to cownose ray foraging.
Oysters were not observed as a primary prey item in rays collected in this study, an observation in agreement with findings from a more comprehensive study of rays feeding near commercial oyster grounds by Fisher (2010). Although rays may prefer thinner shelled bivalves that can be exposed from mud and sand substrates by the combined action of their wings and mouthparts, the presence of predation signatures in oyster shells collected in the present study indicate vulnerability of oyster seed on planted areas, be they in restoration or commercial culture operations. What is evident in the current study is that the shell overlays do not confer protection from ray foraging and that any investment in such overlays will not reap improved economic returns at harvest or survival in restoration mode. What is also evident in this study is the critical nature of the interaction between site location, substrates and local physics to long-term stability of the combined shell foundation - oyster seed planting construct from initial deployment to harvest.

Natural reefs acquire their characteristic shape over decades to centuries as part of a continuing interplay with currents, tides, storm events, and sea level rise. Neither restoration practitioners nor oyster culturists have the luxuries of time and resources to emulate natural structures for their focused needs. Nonetheless, the loss of stable bottom to oyster culture as observed in area D within the time frame of the current study underscores the importance of location-specific knowledge to insuring a successful outcome of either restoration or culture activity. Finally, the interplay of provision of substrate for oyster restoration and culture with preference of rays for feeding on thin-shelled bivalves requires careful thought. A general reduction in these preferred prey items in combination with artificial (shell plants with seed oysters) aggregations of oysters will continue to provide feeding options for rays on oysters when preferred prey are sparse or absent. These substrates do, however, provide both

TABLE 4.

Content of cownose ray stomachs and/or spiral valves collected near the experimental areas in June and July 2012 by weight (g) and percentage $(\%)$ of total.

\begin{tabular}{clcc}
\hline \hline Ray no. & \multicolumn{1}{c}{ Content } & $\begin{array}{c}\text { Stomach } \\
\text { (g/\%) }\end{array}$ & $\begin{array}{c}\text { Spiral } \\
\text { valve (g/\%) }\end{array}$ \\
\hline \multirow{2}{*}{1} & Soft-shell clam (unidentified shell) & - & $4.03 / 99$ \\
& Detritus (woody) & - & $0.04 / 1$ \\
3 & Hard clam (Mercenaria mercenaria) & $2.55 / 57$ & - \\
& Soft-shell clam (Tagelus spp.) & $0.66 / 15$ & $2.18 / 12.4$ \\
& Fish (Brevoortia tyrannus) & $0.28 / 28$ & - \\
& Hooked mussel (Ischadium recurvum) & - & $11.25 / 64$ \\
& Blue crab (Callinectes sapidus) & - & $0.20 / 1$ \\
& Mud crab (Eurypanopeus depressus) & - & $0.14 / 0.3$ \\
& Mud crab (Rhithropanopeus harrisii) & - & $0.06 / 0.8$ \\
& Detritus (plant matter) & - & $0.25 / 1.4$ \\
& Rock (2-mm pebbles) & - & $0.09 / 0.5$ \\
& Unidentified shell and soft tissue & - & $3.45 / 19.6$ \\
Crab body parts, blue crab & - & $2.77 / 32$ \\
& Hooked mussel (I. recurvum) & - & $1.87 / 21$ \\
& Soft-shell clam (Tagelus spp.) & - & $1.2 / 14$ \\
& Unidentified thin shell and soft tissue & - & $2.1 / 24$ \\
& Fish (B. tyrannus) & - & $0.82 / 9$ \\
\hline
\end{tabular}


recruitment surfaces for attached preferred prey such as Ischadium and protection for early recruits of infaunal, thin or thinner shelled species such as Tagelus and Mercenaria. The pre-study surveys noted a general absence of these species, yet by the end of the study Ischadium in particular was abundant in the shallower portions of the experimental areas. Ironically, these long-term or culture restoration structures may provide enhancement for ray-preferred prey species only to insure that when the latter are depleted the rays will turn their attention to the less preferred but abundant oysters.

\section{ACKNOWLEDGMENTS}

This study was supported by $\mathrm{NCBO}$ award number NA11NMF4570227. This project developed from an October 21, 2010, round table discussion among representatives of the Chesapeake Bay Foundation, Virginia Institute of Marine Science, Virginia Marine Resources Commission, the Virginia Seafood Council, Cowart Seafood Corporation, Bevans Oyster Company, NOAA's Chesapeake Bay Office, and the Elasmobranch Society. We appreciate their constructive thoughts. This is contribution number 3529 from the Virginia Institute of Marine Science.

\section{LITERATURE CITED}

Baylor, J. B. 1894. Method of defining and locating natural oyster beds, rocks and shoals. Oyster Records (pamphlets, one for each Tidewater, Virginia County, that listed the precise boundaries of the Baylor Survey). Richmond, VA: Board of Fisheries of Virginia.

Blaylock, R. A. 1989. A massive school of cownose rays, Rhinoptera bonasus, (Rhinopteridae), in Lower Chesapeake Bay, Virginia. Copeia 1989:744-748.

Bros, W. E. \& B. C. Cowell. 1987. A technique for optimizing sample size (replication). J. Exp. Mar. Biol. Ecol. 114:63-71.

DeLury, D. B. 1947. On the estimation of biological populations. Biometrics 3:145-167.

Executive Order 13508. 2009. Chesapeake Bay protection and restoration. May 12, 2009. Washington, DC: White House Office of the Press Secretary.

Fisher, R. A. 2009. Regional workshop on cownose ray issues identifying research and extension needs. VIMS Marine Resource Report 2009-6. VSG-09-06. Gloucester Point, VA: VIMS, College of William \& Mary.

Fisher, R. A. 2010. Life history, trophic ecology, and prey handling by cownose ray, Rhinoptera bonasus, from Chesapeake Bay. Report no. NA07NMF4570324 to National Oceanic and Atmospheric Administration. VIMS Marine Resource Report No. 2010-10. Gloucester Point, VA: Virginia Institute of Marine Science, College of William \& Mary.
Fisher, R. A., G. C. Call \& R. D. Grubbs. 2011. Cownose ray (Rhinoptera bonasus) predation relative to bivalve ontogeny. $J$ Shellfish Res. 30:187-196.

Fisher, R. A., G. C. Call \& R. D. Grubbs. 2013. Age, growth, and reproductive biology of Cownose Rays in Chesapeake Bay. Mar. Coast. Fish. 5:224-235.

Frisk, M. G. 2010. Life history strategies of batoids. In: Carrier, J.C., J. A. Musick \& M. R. Heithaus, editors. Sharks and their relatives II: biodiversity, adaptive physiology, and conservation. Boca Raton, FL: CRC Press. pp. 283-316.

Grusha, D. S. 2005. Investigation into the life history of the cownose ray, Rhinoptera bonasus (Mitchill 1815). MS thesis, Gloucester Point, VA Virginia Institute of Marine Science, College of William \& Mary.

Leslie, P. H. \& D. H. S. Davis. 1939. An attempt to determine the absolute number of rats in a given area. J. Anim. Ecol. 8:93-113.

Mann, R., M. Southworth, J. M. Harding \& J. A. Wesson. 2009. Population studies of the native oyster Crassostrea virginica (Gmelin) in the James River, Virginia, USA. J. Shellfish Res. 28:193-220.

Smith, J. W. \& J. V. Merriner. 1985. Food habits and feeding behavior of the cownose ray, Rhinoptera bonasus, in lower Chesapeake Bay. Estuaries 8:305-310.

Smith, J. W. \& J. V. Merriner. 1987. Age and growth, movements and distribution of cownose ray, Rhinoptera bonasus, in Chesapeake Bay. Estuaries 10:153-164. 